Studia Anglica Posnaniensia 48, 2-3, 2013

doi: 10.2478/stap-2013-0005

\title{
LINGUISTICS
}

\section{OLD ENGLISH ADJECTIVAL AFFIXATION: STRUCTURE AND FUNCTION*}

RAQUEL VEA ESCARZA

University of La Rioja, Logroño

\begin{abstract}
The aim of this article is to carry out a structural-functional analysis of the formation of Old English adjectives by means of affixation. By analysing the rules and operations that produce the 3,356 adjectives which the lexical database of Old English Nerthus (www.nerthusproject.com) turns out as affixal derivatives, a total of fourteen derivational functions have been identified. Additionally, the analysis yields conclusions concerning the relationship between affixes and derivational functions, the patterns of recategorization present in adjective formation and recursive word-formation.
\end{abstract}

Keywords: structural-functional linguistics, Process and Paradigm Morphology, Old English, word-formation, adjective, recursivity

\section{Introduction}

The lexicon of Old English is characterized by the existence of word-formation patterns of affixation, compounding and conversion that operate on a fairly regular and predictable basis. According to Kastovsky (1992: 294), large portions of the lexicon converge formally and semantically thus creating morphologically related word families, a phenomenon typical of Old English, but quite alien to Modern English. As Lass (1994: 198) puts it, the older an IndoEuropean language is, the more transparent word-formation is, and the more central derivational morphology is to the general outfit of the lexicon. However,

* This research has been funded through the project FFI2011-29532, which is thankfully acknowledged. 
as the old Germanic languages evolved, this derivational apparatus became increasingly opaque, either because the formal relationship between the base and the affix was no longer analyzable or because some derivational morphemes had become inflectional. In spite of the opaqueness that arose progressively in Old English word-formation, its lexicon remained remarkably homogeneous and associative and, as such, has drawn considerable attention.

In the area of Old English lexicology and word-formation, a significant part of the previous work has been carried out by Kastovsky $(1968,1971,1986$, 1989, 1990, 1992, 2005, 2006). The Nerthus group has made several contributions to the field, including Martín Arista \& Martín de la Rosa (2006), de la Cruz Cabanillas (2007), García García (2012), González Torres (2010a, 2010b), Guarddon Anelo (2009, forthcoming), Pesquera Fernández (2011), Torre Alonso (2011a, 2011b), Martín Arista (2008, 2009, 2011a, 2011b, 2011c, 2012a, 2012b, 2013, forthcoming) and Martín Arista \& Cortés Rodríguez (forthcoming). However, neither Kastovsky nor the Nerthus group have paid special attention to the lexical class of the adjective. In general, the analyses of the formation of this category that have been carried out so far practically coincide with respect to the inventory of affixes that turn out adjectives as well as the meaning of such affixes (thus Pilch 1970; Jember et al. 1975; Kastovsky 1992; Lass 1994; Quirk \& Wrenn 1994). ${ }^{1}$ Beginning with prefixes, the ones that produce adjectives, according to the works just cited, are given in Figure 1:

$\overline{\mathfrak{x}}$-: it gives the sense of 'without' ( $\bar{x} f e l l e$ 'without skin, peeled') $æ$ fter-: it expresses time (æfterwriten 'written afterwards')

for-: with adjectives it is equivalent to the modification 'very' (forfæger 'very fair')

fore-: it modifies a stem with the sense of 'precedence' or 'pre-eminence' (forehālig 'very holy')

ful-: it gives the sense of 'completeness' (fullboren 'fully born; of noble')

ge-: used with the meaning of assembly or association; with others, no special function can be discerned (gewylde 'powerful, victorious')

in-: it acts as an intensifier (inbyrde 'born on the state')

mis-: it indicates a sense of 'amiss' (misbrōden 'drawn aside')

The structural part of this analysis resorts to standard terminology, in terms of which affixation can be broken down into confixation (when affixes do not interrupt roots and are not interrupted themselves, as in suffixation, prefixation, and interfixation), infixation (when affixes that interrupt roots but are not interrupted themselves), circumfixation (when affixes do not interrupt roots but are interrupted themselves) and transfixation (when affixes interrupt roots and are interrupted by elements of roots themselves). Unlike affixation, compounding involves the binding of two lexeme stems, while conversion takes place when a word assumes the characteristics of a different word-class without any change of form. 
$\bar{o}$-: it is a privative prefix (öhilde 'sloping, inclined')

$o f$-: used primarily with verbs (ofdcel 'inclined downwards')

ofer-: it usually expresses superiority or intensity (ofereald 'very old')

on-/an-: it usually indicates 'against, in reply to', and it is also an intensi-

fier (onswornod 'confused', anforht 'fearful')

or-: it expresses a meaning of 'lacking, without' (orwēne 'hopeless, despairing')

sām-: it modifies adjectives with the sense of 'half' (sāmswā̄led 'halfburned')

sin-: it is used to express 'extensive, lasting' (sinnihte 'eternal night')

purh-: it has the sense of 'through, completely' (burhhwit 'very white')

un-: it has an oppositive meaning (unstille 'moving, changeable, restless')

under-: it forms adjectives with the sense of 'underlying' (undergesett 'placed under')

up-: it forms adjectives with the sense of 'up, away' (üphēah 'uplifted, tall, high')

$\bar{u} t$-: it forms adjectives with the sense of 'out, away' (ütgānde 'outgoing')

wan-: it is a privative prefix (wanhāl 'unsound, weak')

wider-: it modifies adjectives with the sense of 'opposing, counter' (wiðerweard 'contrary, perverse')

Figure 1: Prefixes involved in the derivation of Old English adjectives

Figure 2 lists the suffixes attached to form adjectives in Old English:

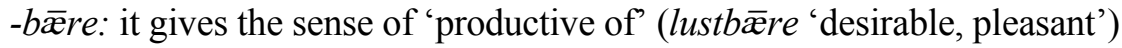
-cund: it forms adjectives meaning 'of the nature of' (déofolcund 'fiendish')

$-e d$ : it forms adjectives usually from nouns (gerǣwed 'arranged in rows')

-en: it forms adjectives out of nouns (brcesen 1 'brazen, of brass')

-end: it forms adjectives from nouns or verbs (oferflowwend 'superfluous, excessive')

-erne: it creates adjectives used with the points of the compass (norðerne 'northern, Northumbrian')

-fæest: it forms adjectives out of nouns (gryrefaest 'terrible firm')

-feald: it is used to form adjectives, especially from numerals (seofonfeald 'seven-fold')

-ful: it forms adjectives out of abstract nouns; sometimes this suffix is added to existing adjectives (diegolful 'mysterious')

-ig: it forms adjectives mainly from nouns (spēdig 'lucky, prosperous')

-iht: it forms adjectives from nouns (scielliht 'having a shell') 
-ing: it gives the sense of 'proceeding or derived from (the stem)'

-isc: it forms adjectives from nouns, including the names of persons and peoples (Grēcisc 'Greek, Grecian')

-lic: it forms adjectives usually from nouns and adjectives (hellic 'of hell, hellish')

-lēas: it forms adjectives out of nouns, with the sense of 'bereft of' (wæstmlēas 'unfruitful')

-ol: it forms adjectives out of verbal stems (hearmcwidol 'evil-speaking, slanderous')

-sum: it forms adjectives, especially from nouns (lufsum 'loving, lovable')

-weard: it forms adjectives with the sense of 'in the direction of' (lāstweard 'successor, heir, follower')

Figure 2: Suffixes that take part in the formation of Old English adjectives

Figures 1 and 2 show, on the one hand, that the formation of adjectives in Old English represents a complex phenomenon comprising a large number of elements, categories and processes. On the other hand, these figures also show that the approach to this phenomenon is not very systematic, given the differences found in the description of units and processes and, above all, meanings. Last but not least, the inventory of affixes is not exhaustive, as is remarked in the analytical part of this article.

It is also worth remarking that the existence of morphologically related sets of lexemes has been discussed under the rather old-fashioned term of word family (thus Kastovsky 1992). This research, on the other hand, resorts to the concept of derivational paradigm, a highly structured set of units with fully explicit rules, operations and relations.

For these reasons, this journal article focuses on the derivation of Old English affixal adjectives in order to fulfill, on the one hand, the necessity of providing an exhaustive description of the units, categories and processes that turn out affixal derived adjectives in Old English and, on the other, a systematic description of adjective formation based on current linguistic theories. In this respect, I draw on the foundations of a structural-functional theory of morphology as laid out by Martín Arista (2008, 2009, 2011a, 2012b) concerning the concept of the word as a field of categories and functions at different levels and recursivity as a defining property of derivational morphology. This research is also based on the paradigmatic model of morphology put forward by Pounder (2000) as regards the notion of the derivational paradigm as comprised of a dynamic (morphological) and a static (lexical) part as well as the inventory of lexical functions, which ultimately dwells on Mel'čuk's $(1996,2006)$ structural morphology. Pounder's (2000) proposal has also the advantage of having been 
applied to derived adjectives in 16th century German, which makes her theoretical model adequate for the description of Old English on areal (Western European) and genetic (West Germanic) grounds.

The data of analysis have been retrieved from the lexical database of Old English Nerthus (www.nerthusproject.com), which contains 30,000 entries, 5,785 of which are adjectives. All non-basic affixal (prefixed as well as suffixed) adjectives have been analysed in this research, totalling 3,356.

With these aims and data of analysis, the article is organized as follows. Section 2 offers an overview of word-formation theory within a structuralfunctional framework, with special emphasis on the derivational functions found in the formation of Old English adjectives. Section 3 unfolds the analysis of Old English adjectives in terms of rules, operations, functions and word slots. To conclude, section 4 yields the conclusions of this research.

2. A structural-functional framework for the analysis of Old English adjective formation

The model of structural-functional morphology proposed by Martín Arista (2008, 2009, 2011a, 2012b, forthcoming) rests on the concept of morphological contrasts as taking place on two different axes. At the paradigmatic axis, morphological contrasts that involve units not more complex than a phrase are established in an open paradigm, namely the derivational paradigm. At the syntagmatic axis, morphological contrasts that consist of units not more complex than a phrase are established in a closed paradigm, the inflectional paradigm. That is, in this framework, morphology manipulates forms with associated meanings in such a way that morphological processes modify forms by adding meaning features to core meanings. Two types of formal change are distinguished. In the first place, formal modification causing meaning extension/restriction comprises one or more choices within a derivational paradigm. And, in the second place, the formal expression that constitutes the paradigmatic implementation of lexemes requires a single choice within an inflectional paradigm. Unlike formal modification, formal expression is context-motivated.

Mel'čuk (2006) establishes a dividing line between morphological and syntactic processes. The six major processes distinguished by this author are: compounding, affixation, suprafixation, replication (string of phonemes that is a copy of the replicant), apophony (also known as ablaut, alternation of sounds within a word that indicates grammatical information, often inflectional), and conversion. These processes can be arranged in a hierarchy determined by the naturalness (frequency) of each process. In this way, Mel'čuk's (2006) proposes the hierarchy presented in Figure 3, thus considering compounding of a different semantic nature: 
Affixation $>$ suprafixation $>$ replication $>$ modification $>$ conversion

Figure 3: Hierarchy of processes by Mel'čuk (2006)

Pounder (2000) claims that there is not yet an integral theory of word-formation semantics that can account for these morphological processes. With the purpose of designing such a theory, Pounder (2000) departs from a distinction between word-formation and lexical meaning. The former is the dynamic side, whereas the latter represents the static side. In other words, word-formation is the processual part, whereas lexical meaning constitutes the result of such a process. Further differences can be found, though. Word-formation meaning is more abstract and lexical meaning is less abstract. A final difference between wordformation and lexical meaning has to do with extralinguistic information, which is excluded from word-formation meaning.

Pounder (2000) also separates the lexical from the morphological units that take part in the processes of word-formation. The meaning of a lexeme tends to be more general than that of word-forms, and it has lexico-syntactic properties, such as class or gender. The word-form requires a lexeme to exist, otherwise a word-form would not be possible. The stem is to be taken as the base for operations. Concerning form rules, they are those affecting the signifiant (perceptible part of a sign) of a lexical or morphological sign. The simplest form rule is the "zero-rule" or identity relation in which the base and product stems are formally identical. This word-formation relation is called conversion. Another type of form rules is the segmental one; within this group we find concatenation or affixation. Non-segmental form rules are accent or tone alternation.

The basic principle underlying a process framework, such as Pounder's (2000) Process and Paradigm Morphology, is that a stem is formally modified in some way, and that this maps onto semantic and/or syntactic modifications. The rule constitutes the basic formative mechanism, whereas the base of the operation is the stem. An operation is formed by the following three elements: the form, the meaning and the conditions to which form and meaning properties are subject to. Word-formation morphological operations, therefore, constitute principled representations, which, moreover, are explicit, given that they have the form displayed in Figure 4:

$$
\begin{aligned}
& <\mathrm{X} \rightarrow \mathrm{Y} ; \text { 'FR' } ; \Sigma>\text {; 'WFO }{ }_{\mathrm{X}} \text { ' } \Sigma> \\
& <f\left({ }^{\prime} \mathrm{X} \text { '); 'SR } \mathrm{X} \text { ' } \Sigma>\right. \\
& <\Sigma_{\mathrm{X}} \rightarrow \Sigma_{\mathrm{Y}} ; \text { ' } \Sigma \mathrm{R}_{\mathrm{X}} \text { ' } \Sigma>
\end{aligned}
$$

Figure 4: Representation of a word-formation operation 
Lexemes are signs of the form $<\mathrm{X}$; ' $\mathrm{X}$ ' ; $\Sigma>$. The word-formation rule morphological operation specifies the base and the affix $(\mathrm{X} \rightarrow \mathrm{Y})$, the derivational function $\left(f(' \mathrm{X}\right.$ ') $)$ and the category change $\left(\Sigma_{\mathrm{X}} \rightarrow \Sigma_{\mathrm{Y}}\right)$, along with the relevant restrictions. In the morphological rule, four kinds of signifiants can be found: (i) signifiants of the general form: $\mathrm{X} \oplus \mathrm{y}$ (derivation), where $\mathrm{y}$ is an affix; (ii) signifiants of the general form $\mathrm{X} \rightarrow \mathrm{Y}$ (conversion); (iii) signifiants of the general form $\mathrm{a} \rightarrow \mathrm{b}$ (modificatory processes), where $\mathrm{a}$ and $\mathrm{b}$ are phonological units in $\mathrm{X}$ and $\mathrm{Y}$ respectively and are defined in $\Sigma$; and (iv) signifiants of the general form: $\mathrm{X} \oplus \mathrm{Y}$ (compounding), where $\mathrm{X}$ and $\mathrm{Y}$ are both stems. The semantic rule is a sign of the form $<f$ (' $\mathrm{X}$ ') ; 'SR $\mathrm{SR}_{\mathrm{X}} ; \Sigma>$, where the signifiant is a function, of which there is a finite set in a given language. The syntactic rule is a sign of the form $<\Sigma_{\mathrm{X}} \rightarrow \Sigma_{\mathrm{Y}}$; ' $\Sigma \mathrm{R}_{\mathrm{X}}$ ' $; \Sigma>$, where the signifiant is a relation between the syntactics of two lexical items.

The list of word-formation functions provided by Pounder (2000) is based on Mel'čuk's (1996) lexical functions, but it is reduced to a total of 17, divided into primary functions, applicable to some or all lexico-syntactic categories, and secondary functions, often used in combination with the primary ones. Lexical functions in Mel'čuk's (1996) structural morphology are defined, in a systematic way, as a set of formal tools designed to describe all types of lexical relations that obtain between units of any language. In this line, an important part of this work has consisted of adapting the set of derivational functions proposed by Pounder (2000) for modern German to Old English.

The following primary functions have been taken directly from Pounder (2000): REL(' $X$ '), which means 'with respect to X'; the function EX(' $X$ '), in which ' $\mathrm{X}$ ' stands for an origin that can be local, causal, or material, depending on the lexical content and the lexico-syntactic category of the stem; the function $\operatorname{LIKE}($ ' $X$ '), in which ' $\mathrm{X}$ ' is a characteristic of ' $\mathrm{X}$ ', and is taken as the basis of a comparison; the function DIM(' $\mathrm{X}$ ') makes ' $\mathrm{X}$ ' smaller or diminished; the function DIST(' $\mathrm{X}$ ') is applied when ' $\mathrm{X}$ ' is a unit of measurement and stands in a distributive relation to something; and, finally, the function I(' $X$ '), which makes ' $X$ ' and $y$ identical, that is, the meaning of ' $X$ ' appears unchanged. In relation to the secondary word-formation functions, these are the ones that have been used without modification with respect to Pounder's proposal: the function PEJ(' $X$ ') evaluates ' $X$ ' negatively, while the function INTENS(' $X$ ') involves a high degree of expressive-emotional intensity or as present in an extraordinary degree. On the other hand, no affixal adjective has been found in the corpus that displays the following lexical functions: $\mathrm{OF}\left({ }^{\prime} \mathrm{X}\right.$ ') 'origin', FOR(' $\mathrm{X}$ ') 'purpose', WITH('X') 'possession', POSS('X') 'possible', PL('X') 'plural', SING('X') 'singular', NEG('X') 'negation', POS(' $X$ ') 'positive' and AUGM(' $X$ ') 'augmentative'. 
The addition of new functions has been governed, to begin with, by the semantics of the lexical class adjective. According to Dixon (2006), adjectives constitute a common property of every human language and a distinguishable class with respect to nouns and verbs. For the great majority of languages, adjectives share these two canonical functions: they indicate that something has a certain property in a statement and help to identify the referent of the head noun in a noun phrase. Functionally speaking, adjectives are more complex and varied than nouns and verbs, and concentrate a higher proportion of derived forms. That is, adjectives often derive from other classes by word-formation means, which are accounted for in the present study in terms of morphological processes.

A total of 9 functions not proposed by Pounder (2000) have been used: firstly, the function NEG(' $X$ ') has been split off into three functions: PRIV(' $X$ '), OPP(' $X$ '), and COUNTFACT(' $X$ '). This typology is based on Martín Arista (2010b), who has dealt with the oppositive, counterfactual, pejorative and privative meanings that can be found under the cover term of lexical negation. Secondly, the function WITH(' $X$ ') has been subdivided into WITHENT(ity)(' $X$ ') and WITHPROP(erty)(' $\mathrm{X}$ '). For this distinction I have taken as reference both the typology of entities adopted by Functional Grammar (Dick 1997a, 1997b) and the Functional Discourse Grammar (Hengeveld \& Mackenzie 2008), according to which entities belong to a higher semantic order than properties. Thirdly, the function STA(tive) draws on the fundamental distinction made by Role and Reference Grammar (Van Valin \& LaPolla 1997; Van Valin 2005) between stative and non-stative predications, which makes allowance for basic Aktionsart classes such as, for instance, states and activities. Concerning the functions LOC(ative)(' $\mathrm{X}$ ') and TEMP(oral)(' $\mathrm{X}$ '), they have been taken from Mel'čuk (1996), although Beard \& Volpe (2005) make a similar proposal. Finally, the figurative function $\operatorname{LIKE}\left(\operatorname{LOC}\left({ }^{\prime} \mathrm{X} '\right)\right)$ is based on Beard \& Volpe, but follows the methodology devised by Pounder (2000) for the definition of nonliteral word-formation functions, and the work by Brinton \& Closs Traugott (2005), which underlies the role played by locative prepositions and adverbs in the development of telic particles throughout a process of grammaticalization of a figurative use. The revised inventory of lexical functions, with an illustration of each, follows in Figure 5:

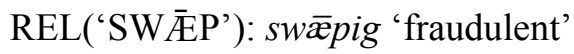

EX('ELETRĒEW'): eletrēowen 'of olive-trees'

LIKE('WUDU'): wudiht 'thick (with trees), garden-like'

DIM('(GE)BÆRNAN'): sāmbærned 'half-burned'

I('NYTT 2'): unnyt 1 'useless, unprofitable'

PRIV('WĪTE'): wìtelēas 'without punishment or fine'

OPP('SCYLDIG'): unscyldig 'guiltless, innocent' 
COUNTFACT('DREFAN'): undrēfed 'untroubled, undisturbed'

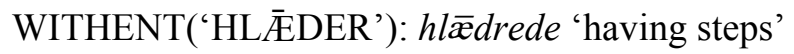

WITHPROP('WYNN'): wunsum 'winsome, pleasant, joyful'

STA('HOSPAN'): hospul 'despised'

TEMP('(GE)WRİTAN'): æfterwriten 'written afterwards'

LOC('INNE 2'): inneweard 1 'internal, inward, inner'

LIKE(LOC('MĒDAN')): inmēde 'close to one's heart'

Figure 5: Inventory of lexical functions used in the analysis

3. The analysis of Old English adjective formation: prefixation and suffixation

The two word-formation processes that take part in the formation of adjectives in Old English are both of an affixal nature: prefixation and suffixation. 1,264 prefixal adjectives and 2,092 suffixal ones, which together make 3,356 affixal adjectives are analysed in this piece of research.

Two types of formalisms have been used in the analysis: rules and operations. As I have remarked above, form rules affect the signifiant of a lexeme and include the zero rule or identity relation and segmental rules dealing with affixation. Semantic rules specify derivational functions, while syntactic rules express the modification of the syntactic properties of a lexeme in producing a new lexeme, that is, they account for the change of syntactic category that takes place. Associated with these, stem conditions specify the sorts of objects the rule may apply to. Finally, the slot in which the operation takes place indicates the degree of recursiveness of the formation: slot-1 operations are non-recursive whereas slot-2 operations are recursive. This applies both to prefixation and suffixation.

In order to carry out an exhaustive analysis of the operations that produce the derivatives discussed in this paper, the following methodological steps were taken. In the first place, I have formulated the form rules that stipulate the affix, base and lexical categories found in the derivation, as in (1):

1) $\quad \mathrm{FR}_{1}<\mathrm{x} \oplus$ ad; ' $\mathrm{FR}_{1}$ '; s.c.: $\mathrm{N}>$

geillerocad from ILLERACU 'surfeit'

The next step I took is the formulation of semantic rules, which account for the word-formation meaning in terms of a derivational function, as in (2):

2) $\quad \mathrm{SR}_{10}<\mathrm{OPP}\left({ }^{\prime} \mathrm{X}\right.$ '); 'SR 10 '; s.c.: $\mathrm{Adj} / \mathrm{Adv} / \mathrm{N} / \mathrm{V}>$

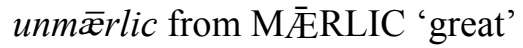


A definition of the syntactic rules responsible for lexical category and meaning changes without change of form was required, as in (3):

3) $\quad \Sigma \mathrm{R}_{1}<\Sigma_{\mathrm{N}} \rightarrow \Sigma_{\mathrm{ADJ}} ;$ ' $\Sigma \mathrm{R}_{1}$ '; s.c.: $\mathrm{N}>$

$\bar{x}$ cen 2 'oaken' from $\bar{\AA} C E N 1$ 'a wood of oaks'

Then, two types of operations have been described: non-recursive operations that take up slot-I, such as prefixation in (4a) and suffixation in (4b), and operations that require an extra slot, slot-II, because slot-I is already occupied. The latter are recursive operations of prefixation and suffixation, illustrated, respectively, by (4c) and (4d):

4)

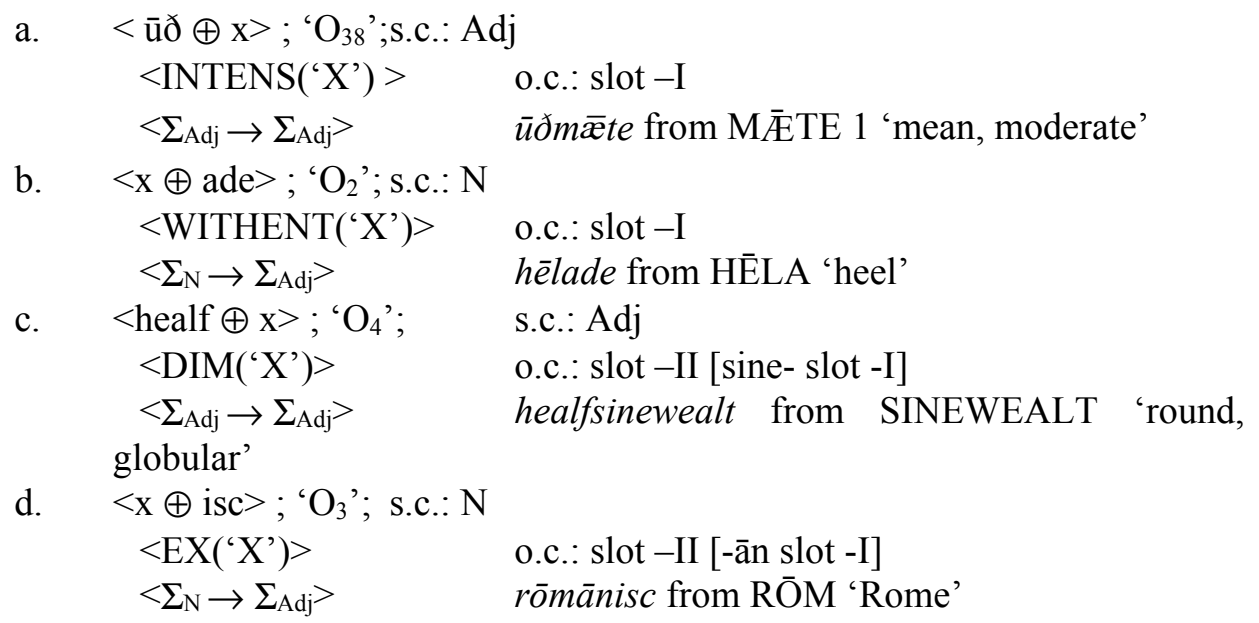

Eighty-eight form rules have been identified that produce derived adjectives in Old English. As illustration, the form rule in (5a) corresponds to prefixed predicates with $\bar{x}$-, and that in (5b) to suffixed predicates with -cund:

5)

a. $\mathrm{FR}_{3}<\overline{\mathrm{x}} \oplus \mathrm{x} ;$ ' $\mathrm{FR}_{3}$ '; s.c.: $\mathrm{Adj} / \mathrm{N} / \mathrm{V}>$

$\bar{x}$ myrce from MIRCE 1 'murky, dark, black'

$\bar{x} g \bar{y} p e$ 'without skill', $\bar{x}$ lenge 1 'lengthy', $\bar{x}$ myrce 'excellent'

$\bar{x}$ melle from MELU 'meal, flour'

$\overline{\mathfrak{x}}$ cnōsle 'degenerate', $\bar{x}$ felle 'without skin', $\bar{x}$ melle 'insipid', $\bar{x} m e n$ 'uninhabitated', $\overline{\mathbf{x}} m \bar{o} d$ 'dismayed', $\overline{\mathbf{x}}$ note 'useless', $\overline{\mathbf{x}}$ tinge 'speechless', $\overline{\mathbf{x}} w \overline{\mathbf{x}} d e$ 'without clothes', $\bar{x}$ wēne 'doubtful' 
$\bar{x}$ gilde from (GE)GYLDAN 1 'to gild'

$\overline{\mathfrak{x}} b l \overline{\mathfrak{x}} c e$ 'lustreless', $\bar{x}$ gilde 'receiving no wergild as compensation', $\bar{x} l \overline{\mathfrak{x}} t e \quad 2$ 'desert'

b. $\mathrm{FR}_{13}<\mathrm{x} \oplus$ cund; 'FR 13 '; s.c.: Adv/N>

incund from INN 2 'in, into, inwards'

feorrancund 'come from afar', incund 'interior', innancund 'inner', innecund 'inward', ufancund 'from above', üpcund 'from above', ütancund 'extraneous' gāstcund from GĀST 'breath; soul'

æðelcund 'of noble birth', dēofolcund 'fiendish', engelcund 'angelic', eorlcund 'noble', eorðcund 'earthly', esnecund 'of a labourer', gāstcund 'spiritual', gesìðcund 'fit to rank as a thane', godcund 'religious', hellcund 'of hell', heofoncund 'celestial', hìwcund 'familiar', metcund 'metrical', mètercund 'relating to metre', sāwolcund 'spiritual', woruldcund 'worldly', yfelcund 'evil'

The rule in (5a) thus stipulates that the prefix $\overline{\mathfrak{x}}$ - precedes the stem, represented by an $\mathrm{x}$, and that these stems may be either adjectives, nouns or verbs. The formulation of the general rule is illustrated with an example of each stem category followed by the list of those adjectival predicates that abide by that particular rule. The rule in $(5 b)$ is applied to suffixed adjectival predicates. In this case, the stem (x) precedes the suffix -cund. This particular suffix requires both adverbial and nominal stems, as indicated in the examples that follow the rule.

Turning to semantic rules, sixteen have been formulated. As illustration, I have chosen the rule for the derivational function DISTributive(' $X$ '), given in (6a), and the one of the function LOCative(' $X$ '), which appears in (6b):

6)

a. $\mathrm{SR}_{2}<\mathrm{DIM}($ ' $X$ '); 'SR 2 '; s.c.: Adj/N/V>

medwīs from WİS 1 'wise, learned'

healfclypigende 'semi-vowel', healfcwic 'half-dead', healfdēad 'healf-dead', healffrēo 'half-free', healfhār 'somewhat hoary', healfhrūh 'half-rough', healfhwit 'somewhat white', healfrēad 'reddish', healfscyldig 'partially guilty', healfsinewealt 'semicircular', medrīce 'of low rank', medspēdig 'poor', medstrang 'of middle rank', medtrum 'weak', medwīs 'dull', sāmcwic 'halfdead', sāmgrēne 'half-green', sāml $\bar{x} r e d$ 'half-taught', twiwyrdig 'ambiguous' twisliht from SLIEHT 'stroke, slaughter'

healffēðe 'lame', healfhundisc 'semi-canine', healfnacod 'half-naked', twiḡ̄ede 'cloven', twisliht 'forked' sāmstorfen from STEORFAN 'to die'

healfbrocen 'half-broken', healfcl̄̄med 'half-plastered', healfclungen 'half- 
congealed', healfeald 'half-grown', healfgewriten 'half-written', healfslǣ pende 'half-asleep', healfsoden 'half-cooked', sāmbærned 'half-burned', sāmboren 'born out of due time', sāmlocen 'half-closed', sāmmelt 'half-digested', sāmsoden 'half-cooked', sāmstorfen 'half-dead', sāmsw⿳亠㐅⿵led 'half-burned', sāmweaxen 'half-grown', sāmwīs 'stupid', twir $\bar{x} d e$ 'uncertain'

b. $\mathrm{SR}_{9}<\mathrm{LOC}($ 'X'); 'SR,'; s.c.: Adj/Adv/N/V>

ofers $\bar{x}$ lic from S $\bar{Æ} L I C$ 'of the sea'

æfterweard 'after', forðgeorn 'eager to advance', hinderweard 'slow', inneweard 1 'internal', ofergylden 'overlaid with gold', oferhyrned 'having horns above', ofers $\bar{x} l i c$ 'on the other side of the sea', üphēah 'uplifted', üplang 'upright', üpriht 'upright', ütāblegned 'ulcerated', ütweard 'outside of' norðeweard from NORĐ 2 'in the north'

æftanweard 'behind', āwegweard 'coming to a close', innanweard 1 'internal', neoðanweard 'lower', niðerweard 'directed downwards', niðeweard 'situated beneath', norðeweard 'northward', sūðeweard 'southwards', ütanweard 'external', üteweard 'external', westweard 2 'westerly' ofdæl from DÆL 'dale, valley, gorge'

éasteweard, ofdæl, ofergyrd, üpfeax ofercæfed from CÆFIAN 'to embroider'

foretimbrigende 'enclosing', forðāgoten 'poured forth', forðbigfērende 'passing by', framlēce 'turned from', inflède 'full of water', ingeseted 'placed in', ingeweaxen 'implanted', inheald 'in bas-relief', insittende 'sitting within', inðicce 'crass', ofercæfed 'overlaid with ornament', oferfroren 'frozen over', oferhan-

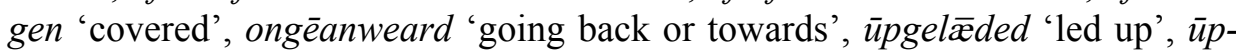
standende 'upstanding', ufeweardl 'upward', understrēowed 'underlaid', ütyrnende 'diuretic'

The rule in (6a) is a semantic rule since it specifies the derivational function displayed by a set of predicates, namely $\operatorname{DIM}(\mathrm{X})$. This function conveys a diminishing meaning to the predicates listed in (6a), among others. Such predicates are arranged in groups depending on the stem category. The rule in (6a) includes a first group with adjectival stems, the second with nominal ones, and the third with verbal ones. The same type of rule is represented in (6b), in this case the derivational function is the locative one $(\operatorname{LOC}(\mathrm{X}))$.

Two syntactic rules are found in the formation of Old English adjectives. Both assign adjectival combinatorial properties to the base, thus cancelling the properties of other lexical categories, as is illustrated by (7a) and (7b). 
7)

a. $\Sigma \mathrm{R}_{1}<\Sigma_{\mathrm{N}} \rightarrow \Sigma_{\mathrm{ADJ}} ;$ ' $\Sigma \mathrm{R}_{1}$ '; s.c.: $\mathrm{N}>$

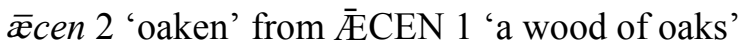

$\overline{\mathfrak{x}} l \overline{\mathfrak{x}} t e 2$ 'desert', $\bar{x}$ lenge 1 'lengthy', $\bar{x} t e r n 2$ 'poisoned', ælmihtig 1 'almighty', æscen 2 'made of ash-wood', cristen 1 'Christian', diegol 1 'secret', dysig 1 'foolish', pēodisc 2 'gentile', eallwealda 1 'all-ruling', forðweard 1 'inclined forwards or towards', fyrlen 1 'far off', (ge) $d w \overline{\mathrm{x}} \mathrm{s} 1$ 'dull', (ge)risne 1 'fit', (ge)t $\overline{\bar{x}} s e 1$ 'pleasant', geðafa 2 'agreeing', gefæd 1 'orderly', gemēde 2 'agreeable', gerād 2 'conditioned', getcel 2 'swift', getīeme 1 'suitable', hālig 1 'holy',

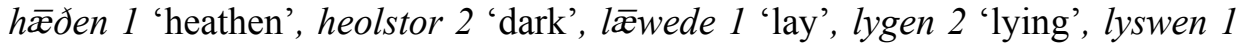
'purulent', mēdren 1 'maternal', medmicel 1 'moderate-sized', mennisc 1 'human', midfeorh 2 'middle-aged', midlen 2 'midmost', oferhygdig 2 'haughty', ofermēde 2 'proud', ofermōd 2 'proud', oferprūt 1 'over-proud', Scyttisc 1 'Scotch', singrēne 2 'evergreen', slidor 1 'slippery', stāniht 1 'stony', twihynde 1 'having wergild of 200 shillings', ütlendisc 1 'strange', ufeweard 1 'upward',

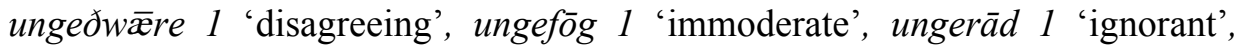

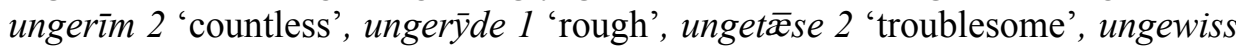
2 'uncertain', ungōd 1 'not good', unmiht 2 'impossible', unnyt 1 'useless', unriht 2 'wrong', uns $\bar{x} d 2$ 'not said', unsōð 1 'untrue', untȳdre 1 'firm', wāol

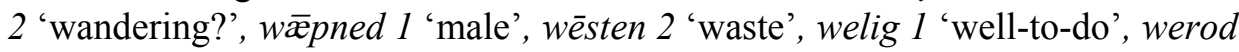
2 'sweet', westweard 2 'westerly', wiðerhȳdig 1 'refractory', wiðerhycgende 1 'refractory', wylfen 1 'wolfish'

b. $\Sigma \mathrm{R}_{2}<\Sigma_{\mathrm{X}} \rightarrow \Sigma_{\mathrm{ADJ}}$; ' $\Sigma \mathrm{R}_{2}$ '; s.c.: Adp, Adv, Pron $>$ andlang 2 'along, by the side of' from ANDLANG 1 'entire, continuous'

tōweard 1 'facing', ufanweard 1 'highest' allefne 2 'universally' from ALLEFNE 1 'quite equal'

ætrihte 1 'right at', allefne 1 'quite equal', frēolslic 1 'festive', Fresisc 1 'Frisian', fulnēah 1 'very near', gehende 1 'near', hiderweard 1 'hitherward', inweard 1 'internal', (ge)lome 1 'frequent', lustb̄̄e 1 'desirable', lȳtel 1 'little', middeweard 2 'middle', nēadwīs 1 'needful', nihterne 1 'nightly', norðweard 1 'north', onriht 1 'right', orm $\bar{x} t e 1$ 'boundless', sūðerne 1 'southern', twigilde 1 'paying double', (ge)tynge 1 'fluent', prigylde 1 'subject to three-fold payment', undēore 1 'cheap', undierne 1 'open', unēaðe 1 'not easy', ungefêre 1 'impassable', ungem $\bar{x} t e l$ 'immense', unhiere 1 'horrible', unnēah 1 'not near', unsȳfre 1 'impure', unweorð 1 'unworthy'

$\bar{x}$ nig 2 'any, any one' from $\bar{Æ} \mathrm{ENIG} 1$ 'any, any one'

$\bar{x}$ nig 2 'any' 
The rule in (7a) is concerned with syntactic processes, more specifically with the source and goal category involved in the process of derivation. In this way, (7a) includes adjectival predicates having a noun as stem. The predicates in (7b) have adpositional, adverbial or pronominal stems.

After dealing with rules, I turn to operations. The following morphological operations insert prefixes into slot-I. The first part of the operation accounts for the affixation process, the second for the derivational function and the third for the pattern of (re)categorization. Notice that the symbol $\oplus$ marks affixation. It follows a prefix and precedes a suffix. In the right column, two types of restrictions are introduced: s.c. stands for "stem conditions" and o.c. for "order conditions". As for the stem conditions, the lexical class of the base has been specified. Regarding order conditions, slot-II is taken up when the operation is recursive, in such a way that the previously inserted affix would occupy slot-I.

In slot-I, 45 operations of prefixation as well as 43 operations of suffixation have been found. (8a) and (8b) illustrate, respectively, prefixation and suffixation in slot-I

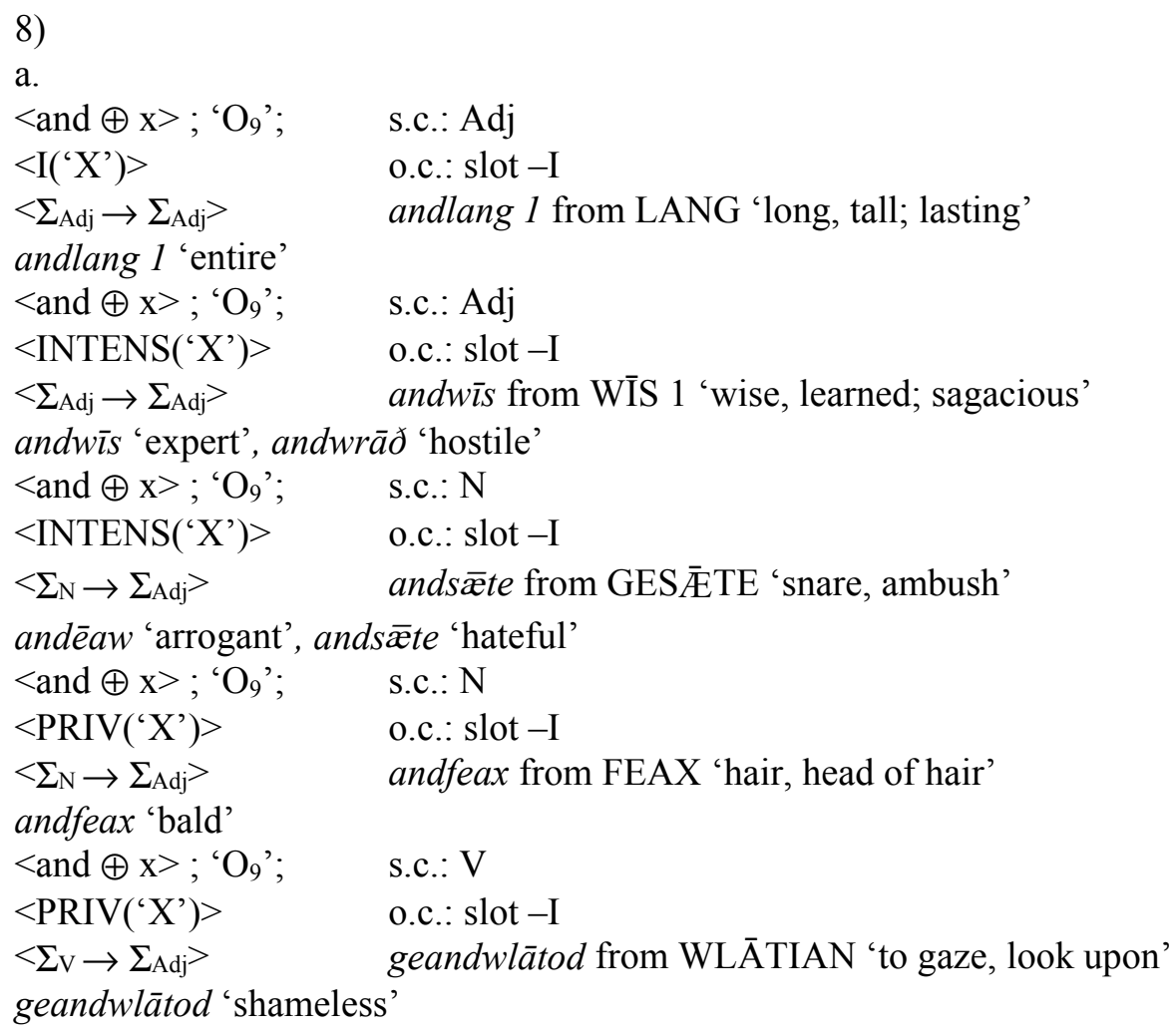


b.

$\begin{array}{ll}<\mathrm{X} \oplus \text { feald }>\text {; ' } \mathrm{O}_{19} \text { '; } & \text { s.c.: Adj } \\ <\operatorname{DIST}\left({ }^{\prime} \mathrm{X} \text { ') }>\right. & \text { o.c.: slot }-\mathrm{I} \\ <\Sigma_{\text {Adj }} \rightarrow \Sigma_{\text {Adj }}> & \text { néahfeald from NĒAH 1 'near, nigh, close; late' }\end{array}$

felafeald 'manifold', manigfeald 'manifold', néahfeald 'intimate'

$<\mathrm{X} \oplus$ feald $>$; ' $\mathrm{O}_{19}$ '; $\quad$ s.c.: $\mathrm{N}$

$<$ DIST(' $X$ ') $>\quad$ o.c.: slot $-\mathrm{I}$

$<\Sigma_{\mathrm{N}} \rightarrow \Sigma_{\mathrm{Adj}}>\quad$ hundfeald from HUND 1 'hundred'

hundfeald 'hundred-fold'

$<\mathrm{x} \oplus$ feald $>$; 'O $\mathrm{O}_{19}$ '; $\quad$ s.c.: Num

$<$ DIST(' $\mathrm{X}$ ') $>\quad$ o.c.: slot $-\mathrm{I}$

$<\Sigma_{\mathrm{Num}} \rightarrow \Sigma_{\mathrm{Adj}}>$ eahtafeald from EAHTA 'eight'

ānfeald 'single', eahtafeald 'eightfold', endlyfenfeald 'eleven-fold', fēowerfeald 'four-fold', fēowertigfeald 'forty-fold', fiffeald 'fifty-fold', fiftigfeald 'fiftyfold', fiðerfeald 'four-fold', hundseofontigfeald 'seventy-fold', hundseofontigseofonfeald 'seventy-seven-fold', hundtēontigfeald 'hundred-fold', nigonfeald 'nine-fold', seofonfeald 'seven-fold', siexfeald 'six-fold', sixtigfeald 'sixtyfold', tīenfeald 'ten-fold', twelffeald 'twelve-fold', twèntigfeald 'twenty-fold', prifeald 'three-fold', pritigfeald 'thirty-fold', püsendfeald 'thousand-fold'

These operations compile all the relevant information that define a predicate in terms of its morphological, syntactic and semantic aspects relevant to wordformation. Focusing on (8a), the first part of the operation specifies the affix (and-) and the stem category (adjective); the second part indicates the derivational function performed by the affix, together with the kind of predicate in terms of recursivity. Slot-I stands for the first level of recursivity, that is, a predicate consisting of a stem and an only affix (or, in other words, the derivation of an underived base). Finally, the third part of the operation comprises the source and goal categories of the predicates involved in the process of derivation, together with an example.

After presenting the analysis of non-recursive adjectival affixation in slot-I, I concentrate on recursive derivation. Affixes attached to already affixed words require an extra position, slot-II, because slot-I is taken up by the affix inserted in the previous operation. In slot-II, six operations of prefixation and five of suffixation can be distinguished, illustrated, respectively, by (9a) and (9b):

9)

a.

$<$ healf $\oplus \mathrm{x}>$; ' $\mathrm{O}_{4}$ '; $\quad$ s.c.: Adj

$<$ DIM $\left({ }^{\prime} \mathrm{X}\right.$ ') $>\quad$ o.c.: slot -II [sine- slot -I]

$<\Sigma_{\mathrm{Adj}} \rightarrow \Sigma_{\mathrm{Adj}}>\quad$ healfsinewealt from SINEWEALT 'round, globular' 
healfsinewealt 'semicircular'

$<$ healf $\oplus \mathrm{x}>$; ' $\mathrm{O}_{4}$ '; $\quad$ s.c.: $\mathrm{V}$

$<\operatorname{DIM}\left({ }^{\prime} \mathrm{X}\right.$ ') $>\quad$ o.c.: slot - II [ge- slot -I]

$<\Sigma_{\mathrm{V}} \rightarrow \Sigma_{\mathrm{Adj}}>\quad$ healfgewriten from (GE)WRĪTAN 'to incise, engrave'

healfgewriten 'half-written'

b.

$<\mathrm{x} \oplus$ lēas $>$; ' $\mathrm{O}_{4}$ '; $\quad$ s.c.: $\mathrm{N}$

$<$ PRIV('X') $\quad$ o.c.: slot -II [-en, -end slot -I]

$<\Sigma_{\mathrm{N}} \rightarrow \Sigma_{\text {Adj }}>\quad$ feormendléas from FEORMEND 2 'cleanser, polisher'

feormendlēas 'wanting a burnisher', pēodenlēas 'without a ruler or chief'

The operations in (9) follow the same structure as those in (8), although those in (9) contain a second level of recursivity, represented with slot-II. For instance, the predicate in (8a) healfsinewealt contains two affixes attached to a stem: sine-, belonging to the first level of recursivity, and healf- to the second. We are dealing, consequently, with the derivation of derived bases.

\section{Results of the analysis and conclusion}

To summarize, this work has drawn on the structural-functional model of morphology put forward by Martín Arista (2008, 2009, 2011a, 2012b) regarding two theoretical questions. In the first place, the defining properties of derivational morphology are recategorization and recursivity. Secondly, wordformation meanings are accounted for by means of functional relations. In this respect, I have followed Pounder (2000) for the proposal of functions, which can be traced back to Mel'čuk's $(1996,2006)$ structural theory of morphology. On the analytical side, this piece of work has used a corpus of 3,356 adjectival predicates extracted from the Nerthus database with the aim of analyzing the derivation of Old English affixal adjectives, of which 3,356 can be found in Nerthus. If the figures of compounds $(1,419)$, and zero derivatives (512) are added to the total of affixal adjectives, the picture that emerges is one of a derived class: most of the 5,785 Old English adjectives are derived by the means just explained.

From the descriptive point of view, the analysis has turned out an exhaustive inventory of the affixes involved in adjective formation. The prefixes attached to derived adjectives are $\bar{a}-, \bar{x}-, \bar{x} g-, \mathfrak{x} f-$, æfter-, æl-, æle-, æt $t$-, al-, am-, an-, and-, be-, bì-, eal-, eall-, ed-, el-, ell-, for-, forð-, fore-, fram-, frēa-, ful-, full-, (ge)-, ge-, gēan-, geond-, healf-, in-, med-, mis-, ō-, of-, ofer-, on-, or-, or-, sam-, sin-, sine-, tō-, twi-, pri-, purh-, pry-, ūð-, ūp-, $\bar{u} t-$, un-, under-, wan-, wiðer- and ymb-. The suffixes attached to derived adjectives are -ða, -ad, -ade, 


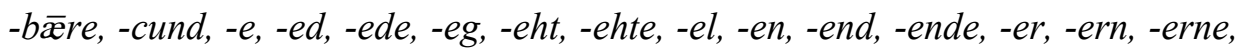
-es, -et( $t$ ), -færst, -feald, -ful, -ga, -ic, -iende, -ig, -ige, -iht, -ihte, -ing, -isc, -lēas, -lic, -n, -od, -ode, -ol, -or, -sc, -sum, -ta, -te, -u, -ud, -ul, -um, -weard, -welle, -wende and -wīs.

On the explanatory side, this research has contributed in what respects the relationship between derivational functions and affixes (and vice versa), recategorization and recursive word-formation.

Beginning with the relationship holding between derivational functions and affixes, the conclusion can be drawn that a one-to-one correspondence between derivational functions and affixes is the exception rather than the rule. There are only two functions that are realized only by an affix: PEJ(X) and COUNTFACT $(\mathrm{X})$, whereas the functions that are realized by more than one affix include $\operatorname{PRIV}(\mathrm{X}), \quad \mathrm{OPP}(\mathrm{X}), \quad \operatorname{DIST}(\mathrm{X}), \quad \mathrm{DIM}(\mathrm{X}), \quad \operatorname{INTENS}(\mathrm{X})$, WITHENT(X), WITHPROP(X), EX(X), STA(X), TEMP(X), LOC(X), $\operatorname{LIKE}(\operatorname{LOC}(\mathrm{X}))$, $\operatorname{LIKE}(\mathrm{X}), \operatorname{REL}(\mathrm{X})$, and $\mathrm{I}(\mathrm{X})$.

Turning to the relationship between affixes and derivational functions, it is worth pointing out that most affixes perform more than one derivational function. To be more precise, 37 prefixes (out of 56) and 30 suffixes (out of 51) serve more than one function. The difference between prefixation and suffixation in this respect is not significant: more than one half of both prefixes and suffixes is associated with more than one derivational function. These data strongly indicate that affixation is not free from polysemy and that descriptions of affixes such as the ones reviewed in Figures 1 and 2 tend to oversimplify this question by providing the more central or frequent meanings conveyed by the affixes exclusively.

Regarding recategorization, prefixation displays three different patterns denoting a change of category, including $<\operatorname{Adj} \rightarrow \operatorname{Adj}>,<\mathrm{N} \rightarrow \operatorname{Adj}>$, and $<\mathrm{V} \rightarrow$ $\operatorname{Adj}>$, and there are five different ones in the case of suffixation: $<\operatorname{Adj} \rightarrow \operatorname{Adj}>$, $<\operatorname{Adv} \rightarrow \operatorname{Adj}>,<\mathrm{N} \rightarrow \operatorname{Adj}>,<\mathrm{Num} \rightarrow \operatorname{Adj}>$, and $<\mathrm{V} \rightarrow \operatorname{Adj}>$. As for the relationship between the base category and the derivational function, most functions apply to bases of more than one category, the functions $\mathrm{REL}\left({ }^{\prime} \mathrm{X}\right.$ ') and $\operatorname{LIKE}\left(\operatorname{LOC}\left({ }^{\prime} X\right.\right.$ ')) being the ones that display a greater diversity of base categories: the bases corresponding to the predicates with the function REL(' $\mathrm{X}$ ') are adjectives, adverbs, nouns, numerals, possessives, pronouns, and verbs; whereas in the case of $\operatorname{LIKE}(\operatorname{LOC}(' X$ '), we find adjectives, adpositions, adverbs, nouns, and verbs. There are three derivational functions whose predicate bases belong to one category only, including the function COUNTFACT(' $\mathrm{X}$ '), having only verbal bases, the function $\operatorname{LIKE}\left({ }^{\prime} X\right.$ '), containing nominal bases, and the function TEMP(' $X$ '), applying exclusively with verbal ones. In this, the base of derivation to which the same affix is attached does not necessarily belong to the same category. For instance, the suffix -en, whose predicates have bases be- 
longing to the category adjective, noun, numeral, and verb; or the more productive suffix -lic, which partakes in predicates whose bases are adjectives, adverbs, nouns, numerals, possessives, pronouns, and verbs. There are a few exceptions to this general tendency, for example all the predicates with the prefix in- and the suffix -ol have a verbal base.

Two levels of recursivity have been distinguished: recursivity with a nonrecursive base and recursivity with a recursive base. There is not a great difference between recursivity in prefixation and in suffixation as displayed by affixal adjectives. Six recursive operations have been found in recursive prefixation and five in recursive suffixation. When the different patterns of recategorization that take place in recursive operations are taken into account, though, a wider gap appears between the two operations: there are 18 patterns of recategorization in prefixation and 14 in suffixation. For instance, the prefix on- occurs in operations that require the recategorization adjective $>$ adjective (onfordōn), noun $>$ adjective (ongeflogen) and verb $>$ adjective (ontōblāwen). Regarding recursivity, it has also turned out that the suffix -lic is, by large, the most recursive affix in adjective formation both in quantitative and qualitative terms. Regarding quantification, I have identified 2 recursive patterns with adverbial base, 10 with verbal base, 15 with nominal base and 24 with adjectival base. In qualitative terms, -lic is the only affix that takes part in derivatives that display a double pattern of recursivity, that is, whose base of derivation is not simply derived but recursively derived before undergoing further affixation. Examples in point are dēawigendlic and wìtigendlic (from adjectives) æt $\bar{y}$ wigendlic, forhogigendlic, gebīcnigendlic, hatigendlic, (ge)herigendlic, miltsigendlic, tōclypigendlic (from nouns) and āfandigendlic, āscirigendlic, āslacigendlic, ātēorigendlic, blissigendlic, clipigendlic, declīnigendlic, dwoligendlic, framigendlic, fremigendlic, geniðerigendlic, getācnigendlic, healsigendlic, hēofigendlic, iersigendlic, nemnigendlic, swerigendlic, syndrigendlic, (ge)tēorigendlic, turnigendlic, purhwunigendlic, wundrigendlic (from verbs).

To conclude, the analysis of recursivity shows that there is no double recursivity in prefixation, which conforms to the maximal degree of complexity in Old English derivational morphology found by Martín Arista (2008), whereas there is double recursivity in suffixation, as in dēawigendlic 'dewy; moist'.

\section{REFERENCES}

Beard, Robert \& Mark Volpe. 2005. Lexeme-morpheme base morphology. In Pavol Stekauer \& Rochelle Lieber (eds.), Handbook of word-formation, 189-205. Dordrecht: Springer. 
Brinton, Laurel \& Elizabeth Closs Traugott. 2005. Lexicalization and language change. Cambridge: Cambridge University Press.

de la Cruz Cabanillas, Isabel. 2007. Semantic primes in Old English: A preliminary study of descriptors, SELIM 14. 37-58

Dik, Simon. 1997a. The theory of Functional Grammar. Part 1: The structure of the clause. Kees Hengeveld (ed.). Berlin: Mouton de Gruyter.

Dik, Simon. 1997b. The theory of Functional Grammar, Part 2: Complex and derived constructions. In Kees Hengeveld (ed.). Berlin: Mouton de Gruyter.

Dixon, Robert M. Ward. 2006. Adjective classes in typological perspective. Robert M. Ward Dixon \& Alexandra Aikhenvald (eds.), Adjective classes: A cross-linguistic typology, 1-48. Oxford: Oxford University Press.

García García, Luisa. 2012. Morphological causatives in Old English: the quest for a vanishing formation. Transactions of the Philological Society 110(1). 112-148.

González Torres, Elisa. 2010a. The continuum inflection-derivation and the Old English suffixes $-a,-e,-o,-u$. ATLANTIS 32(1). 103-122.

González Torres, Elisa. 2010b. The bases of derivation of Old English affixed nouns: Status and category. Studia Anglica Posnaniensia 46(2). 21-43.

Guarddon Anelo, Maria del Carmen. 2009a. The natural semantic metalanguage of Old English compound adpositions. English Studies 30. 61-83.

Guarddon Anelo, Maria del Carmen. 2009b. Un análisis de las propiedades combinatorias de los primitivos semánticos a través de las adposiciones complejas en inglés antiguo. Revista Española de Lingüística 39(2). 93-122.

Hengeveld, Kees \& John Lachlan Mackenzie. 2008. Functional Discourse Grammar. A typologically-based theory of language structure. Oxford: Oxford University Press.

Jember, Gregory K., John C. Carrell, Robert P. Lundquist, Barbara M. Olds \& Raymond P. Tripp Jr. 1975. English-Old English, Old English-English Dictionary. Boulder, Colorado: Westview Press.

Kastovsky, Dieter. 1968. Old English deverbal substantives derived by means of a zero morpheme. Tübingen: Eberhard-Karls-Universität dissertation.

Kastovsky, Dieter. 1971. The Old English suffix -ER(E). Anglia LXXXIX(3). 285-325.

Kastovsky, Dieter. 1986. Deverbal nouns in Old and Modern English: From stem-formation to word-formation. In Jacek Fisiak (ed.), Historical semantics - Historical word formation, 221-261. Berlin: Mouton de Gruyter.

Kastovsky, Dieter. 1989. Typological changes in the history of English morphology. In Udo Fries \& Martin Heusser (eds.), Meaning and beyond. Ernst Leisi zum 70. Geburstag. Tübingen: Gunter Narr Verlag. 281-293.

Kastovsky, Dieter. 1990. The typological status of Old English word formation. In Sylvia Adamson, Vivien Law, Nigel Vincent \& Susan Wright (eds.), Papers from the $5^{\text {th }}$ International Conference on English Historical Linguistics, 205-224. Amsterdam: John Benjamins.

Kastovsky, Dieter. 1992. Semantics and vocabulary. In Richard Hogg (ed.), The Cambridge history of the English language I: The beginnings to 1066, 290-408. Cambridge: Cambridge University Press.

Kastovsky, Dieter. 2005. Conversion and/on zero: Word-formation theory, historical linguistics, and typology. In Laurie Bauer \& Salvador Varela (eds.), Approaches to conversion/zero derivation, 31-50. Münster: Waxmann. 
Kastovsky, Dieter. 2006. Typological changes in derivational morphology. In Ans Van Kemenade \& Bettelou Los (eds.), The handbook of the history of English, 151-177. Oxford: Blackwell.

Lass, Roger. 1994. Old English: A historical linguistic companion. Cambridge: Cambridge University Press.

Martín Arista, Javier. 2008. Unification and separation in a functional theory of morphology. In Robert Van Valin (ed.), Investigations of the syntax-semantics-pragmatics interface, 119-145. Amsterdam: John Benjamins.

Martín Arista, Javier. 2009. A typology of morphological constructions. In Christopher S. Butler \& Javier Martín Arista (eds.), Deconstructing constructions, 85-115. Amsterdam: John Benjamins.

Martín Arista, Javier. 2011a. Projections and constructions in Functional Morphology. The case of Old English HRE $\bar{O}$. Language and Linguistics 12(2). 393-425.

Martín Arista, Javier. 2011b. Adjective formation and lexical layers in Old English. English Studies 92(3): 323-344.

Martín Arista, Javier. 2011c. Morphological relatedness and zero alternation in Old English. In Pilar Guerrero Medina (ed.), Morphosyntactic alternations in English, 339-362. Sheffield/ Oakville: Equinox.

Martín Arista, Javier. 2012a. The Old English prefix ge-: A panchronic reappraisal. Australian Journal of Linguistics 32(4). 411-433.

Martín Arista, Javier. 2012b. Lexical database, derivational map and 3D representation. RESLARevista Española de Lingüistica Aplicada Vol. Extra 1. 119-144.

Martín Arista, Javier. 2013. Recursivity, derivational depth and the search for Old English lexical primes. Studia Neophilologica 85(1). 1-21.

Martín Arista, Javier. Noun layers in Old English. Forthcoming.

Martín Arista, Javier \& Francisco Cortés Rodríguez. From directionals to telics: Meaning construction, word-formation and grammaticalization in Role and Reference Grammar. In Maria Ángeles Gómez González, Francisco Ruiz de Mendoza Ibáñez \& Francisco Gonzálvez García (eds.), Form and function in language: Functional, cognitive and applied perspectives. Amsterdam: John Benjamins. Forthcoming.

Martín Arista, Javier \& Victoria Martín de la Rosa. 2006. Old English semantic primes: Substantives, determiners and quantifiers. ATLANTIS 17. 9-28.

Mel'čuk, Igor. 1996. Lexical functions: A tool for the description of lexical relations in the lexicon. In Leo Wanner (ed.), Lexical functions in lexicography and natural language processing, 37-102. Amsterdam: John Benjamins.

Mel'čuk, Igor. 2006. Aspects of the theory of morphology. Berlin: Mouton de Gruyter.

Pesquera Fernández, Laura. 2011. Productivity of type in the derivational paradigm of Old English strong verbs. Revista de Lingüistica y Lenguas Aplicadas 6. 299-310.

Pilch, Herbert. 1970. Altenglische Grammatik. München: Max Hueber Verlag.

Pounder, Amanda. 2000. Processes and paradigms in word-formation morphology. Berlin: Mouton de Gruyter.

Quirk, Randolph \& Charles Leslie Wrenn. 1994 [1955]. An Old English grammar. DeKalb, Illinois: Northern Illinois University Press.

Torre Alonso, Roberto. 2011a. The morphological structure of Old English complex nouns. ATLANTIS 33(1). 127-146.

Torre Alonso, Roberto. 2011b. Nominal affix combinations in Old English: Distribution and restrictions. Revista Española de Linguística Aplicada-RESLA 24. 257-279. 
Van Valin, Robert. 2005. Exploring the syntax-semantics interface. Cambridge: Cambridge University Press.

Van Valin, Robert \& Randy LaPolla. 1997. Syntax: Structure, meaning and function. Cambridge: Cambridge University Press. 